\title{
SURVEY AND DISTRIBUTION OF THE RESIDENT AND MIGRATORY WILD BIRD SPECIES IN DIFFERENT HABITATS AT GHARBIA GOVERNORATE
}

\author{
A. M. Metwally ${ }^{(1)}$, M. A. Mostafa(1), Hala M. Gamal El-Din ${ }^{(2)}$, \\ M.A. El-Danasory ${ }^{(1)}$ and Noura M. Barakat ${ }^{(2)}$ \\ ${ }^{(1)}$ Faculty of Agriculture, Al-Azhar University, Cairo, Egypt \\ (2) Faculty of Home Economics, Al-Azhar University, Tanta, Egypt
}

Received: Oct. 4, 2016

Accepted: Oct. 15,2016

\begin{abstract}
This work was conducted to survey and know distribution of some wild bird species at Gharbia Governorate during two successive years (2012-2014). Twenty four bird species were recorded as resident birds were classified to fourteen as harmful bird species and 10 species were recorded as beneficial birds. These species were existed around the year. Five bird species as migratory bird species recorded during the study period were as follow, four species were recorded as harmful birds and one species was recorded as beneficial bird species.
\end{abstract}

Key words: Bird species, beneficial bird species, harmful bird species, bird ecology

\section{INTRODUCTION}

In Egypt, the number of bird species were 515 the resident birds are 186 bird species, 12 are extinct and 17 are ere endemic, while the rest of bird species and sub species 300 species are migratory (Tharwat, 1997). In Egypt, horizontal expansion, through reclamation of desert lands create a new habitats for birds where food supplies and a suitable places for life and the reproduction. Some bird species are considered the most important agricultural pests in many crops, vegetables and fruits such as wheat, barley, rice, maize, tomato, squash, cucumber, grape, apple and strawberry (Khattab 1993, Tharwat 1997, Bonnah 2007, Khattab et al.. 2002, Attia 2006, Omar 2010 and Attia 2013). Essa (1993) observed bird species at Nubaria area during 1990 and classified into beneficial birds and noxious birds, furthermore, It was evident that the study selected area was rich with beneficial bird species; Cattle egret, Egrett ibis and Great gray shrike, Lanius excubitor, where the most prevalent beneficial species all over the year months was White wagtail, Motacilla alba and Black headed gull Birds which surveyed in old land and newly reclaimed land through the different seasons of the year, also House sparrow, Passer domesticus niloticus, was the most prevalent species in both lands, while In old land, Palm dove Streptopelia senegalensis s., is ranked in second rank followed by Hooded crow Corvus corone cornix, and Crested lark, Galerida cristata nigricans. Crested lark was the second followed by Hooded crow Corvus corone cornix, Palm dove Streptopelia sengalensis s., Spanish sparrow Passer hespaniolensis $h$. and Starling Sturnus vulgaris, were recorded only during Autumn and Winter as visitors with different abundance at the tested areas Khattab (1993). The House sparrow Passer domesticus niloticus, was the predominant noxious bird species at Kafr El-Sheikh Governorate, while Palm dove Streptopelia sengalensis s., and Crested lark Galerida cristata nigricans, ranked in the second order after House sparrow Soliman (1999) and Wilson (1993). House sparrow Passer domesticus niloticus was the most prevalent species in both old and newly reclaimed lands, throughout year seasons. In old land, Palm dove, Streptopelia senegalensis ranked the second followed by Hooded crow C. corone cornix and Crested lark, Galerida 
cristata. On the other hand, Crested lark was second in the newly reclaimed lands followed by Hooded crow and Palm dove. For the beneficial bird species, Cattle egret, Bubulicua ibis, recorded as resident with highly abundance in the two tested areas, while Swallow Hirundo rustica and Wagtail Motacilla alba were recorded only during Autumn, Winter and Spring seasons as visitors EL-Deeb et al. (1995). Cattle egret bird preferred open cultivated areas occupied by grazing cattle, but it was absent in fallow and salin lands. Cattle egret was found in all districts of Kafr EL- Sheikh Governorate except Baltim and Metobus, and their numbers considerably differed from one district to another. Palm dove birds were recorded in fields, buildings and shouna of the ten counties belonging to Kafr ELSheikh Governorate. Shouna harbored the highest number of Palm dove birds followed by buildings while the lowest number was recorded in fields. House sparrow birds were recorded in field, buildings and shouna of the ten districts belonging to Kafr EL- Sheikh Governorate Soliman (1999). The avifauna in Abbassa pond at Sharkia Governorate have many kinds of wild birds. Some of these birds are migratory (13species), but others are resident (16species). Avifauna community of Abbassa pond inhabited by some of noxious birds that feed on small fish in fish farm located in this area such as Blue-kingfisher, Black-headed gull, White stork and other species of the family Anatidae considered as migratory birds, while Gray heron, Purple heron, Little egret, Cattle egret and Pied kingfishers as resident once Khattab et al. (2002). Palm dove, (Streptopelia senegalensis) showed a significant difference in habitat, while there was no significant variance between the population density for the two years (1998 \& $1999)$ at EL-Monofia governorate. The House sparrow (Passer domesticus niloticus) showed a high significant difference between the population density at this bird under different habitats through the two years EL-Danasory (2002). The birds were 23 resident bird species and 5 migratory bird species under the different orders. The resident wild bird species were (Passeriformes) House sparrow, Hooded crow, Swallow, Fantailed warbler, Crested lark, Nile valley sunbird, Sand-martin, Desert wheatear and White vented bulbul. Also (Columbiformes), Palm dove and Rock dove, (Ciconiformes) Cattle egret, (Charadruformes) spur winged plover and Senegal stone curlew, (Coraciformes) Little green bee-eater, Pied kingfisher and Hoopoe, (Gruiformes) Moorhen and (Strigiformes) Barn owl and little owl, while the migratory wild bird species were (Passeriformes) White wagtail, Yellow headed wagtail, Blue throat and Chiffchaff Omar (2005). The resident birds in ElMenoufia Governorate, these species were Common bulbul, Pycnonatus barbatus, Crested lark, Galerida cristata, Goldfinch, Carduelis carduelis nedicki, Great grey shrik, Lanus excubitor, Hooded crow, Corvus corone cornex, hoopoe, Upupa epops epops, House sparrow, Passer domesticus niloticus, Little bee-eater, Merops orientalis cleoptara, Palm dove, Streptopelia senegalensis, Senegal cucal, Centropus senegalensis, Spotted senegalensis, Ptercles senegallus, Spurwinged plover, Hoplopterus spenosus, Swallow, Hirundo rustica savignii, Yellow wagtail, Motacilla flava, and Graceful warbler, Prinia gracilis. The aquatic birds including two species: this species were Cattle egret, Ardeola ibis ibis and the Moorhen, Gallinula chloropus. Raptor birds were represented by three species: these species were Black shoulder kite, Elanus caerules, Kestrel, Falco tinnunculus and Black kite Milvus migrans EL-Danasory (2006).The resident wild bird species of order Passeriformes were the dominant wild birds included eleven families, and the House sparrow Passer domesticus is the most wild bird species extent in the three ecosystem of Sharkia Governorate Attia (2006). Hooded crow Corvus corone sardonius in all habitats of four tested governorates (Sharkia, Qalubia, Ismailia and 
Suez), while Brown-necked raven Corvus corax ruficollis was only found at Ismailia and Suez Governorates Hassan (2008). Twenty seven resident bird species were recorded at Ismailia governorate. The resident wild bird species of order Passeriformes were the dominant wild birds included ten families, contain on six genera and eight species were recorded as harmful species, while six bird species were as migratory birds Linnet, Carduelis cannabina, White wagtail, Motacilla alba alba, Chiffchaff, Phelloscobus collybita, Stonechat Saxicola torquata, White stork, Ciconia ciconia and Kingfisher, Alcedo atthis Attia (2013).

\section{MATERIALS AND METHODS Survey and distribution of the wild bird species:}

This work had been conducted at four different habitats representing different environmental and ecological areas at Gharbia Governorate. These habitats were nearby each of (buildings, field crops, trees and water canals). The field trails started from October 2012 to September 2014.

The birds either residents or migratory were surveyed in Tanta and Zifta district at Gharbia Governorate. In these trails, area size is two feddans inside the chosen cultivated Location. Number of the different bird species was counted in each habitat by using the method of Redinger and Libay (1979) as a plot equivalent two feddans from the determined cultivated area in each location. The identification and counts of bird species were achieved by using field glass (binoculars) from rising position, which gave clear sighted vision of the plots. This work has been accomplished twice daily, the first at sunrise and second at sunset during one hour for sex successive days monthly. Bird classification were carried out by (Sibley and Monoroe 1990) under review by the checklist committee of the American Ornithologists Union (A. O. U.) were followed in bird classification.

\section{RESULTS AND DISCUSSION Survey of some wild bird species: Survey and distribution of some resident wild bird species:}

Data in Table (1) indicated that, the resident wild bird species recorded during the study period were as follow, 14 species were recorded as harmful birds and 10 species were recorded as beneficial birds belonging to 20 families and 10 orders. These species were existed around the whole year and recorded a highly significant difference between the numbers of bird species in the different districts.

These resident wild bird species were classified according to their orders as follow:-

Order Charadriiformes was represented by three bird species, Greater Painted snipe Rostratula benghalensis belonging to family Rostratulidae was found in Tanta district only, Spur-winged plover Hoplopterus spenosus belonging to family Charadriidae, Senegal thick nee Burhinus senegalensis belonging to family Burhinidae were found in two districts as beneficial bird.

Order Ciconiformes was represented by three bird species Cattle egret Bubulcus ibis ibis, Little egret Egretta garzetta and Squacco heron Ardeola ralloides as beneficial species belonging to family Ardeidae were found in two districts. Order Columbiformes and family Columbidae was represented by one bird species Palm dove Streptopelia senegalensis as harmful species which was found in two districts.

Order Coraciformes was represented by two bird species were recorded as harmful species belonging to two families Cerylidae and Meriopidae. These species were Pied kingfisher Ceryle rudis and Little green beeeater Merops orientalis found in two districts.

Order Cuculiformes was represented by one bird species which were recorded as beneficial species belonging to family Centropidae Senegal coucal Centropus 
senegalensis was found in Tanta district.

Order Falconiformes include one bird species were recorded as beneficial species belonging to family Falconoidae Kestrel Falco tinnunculus found in two districts.

Order Gruiformes included two birds as harmful species Moorhen Gallinula chloropus found in two district and Water rail Rallus aguaticus which was recorded in Tanta only belonging to family Rallidae.

Order Passeriformes with eight families (Alaudidae, Cisticolidae, Corvidae, Hirundidae, Motacillidae, Nectariniidae, Passeridae, and Pycnonotidae) with six species were recorded as harmful bird.
These species were (Crested lark Galerida cristata), (Grecful warbler Prinia gracilis), (Hooded crow Corvus corone cornix), (Nile valley sunbird Anthreptes metallicus), (House sparrow Passer domesticus niloticus) and (Fan tailed warbler Cisticola juncides), while three species were recorded as beneficial (Yellow wagtail Motacilla flava), (Swallow Hirundo rustica savignii) and (Common bulbul Pycnonotus barbatus). All these species were found at two districts expected Crested lark Galerida cristata and Yellow wagtail Motacilla flava were absent from Zifta district.

Table (1): Survey and distribution of some resident wild bird species at Gharbia Governorate during October 2012 to September 2014

\begin{tabular}{|c|c|c|c|c|c|c|c|c|c|c|c|}
\hline \multirow[t]{3}{*}{ Orders } & \multirow[t]{3}{*}{ Families } & \multicolumn{2}{|c|}{ Resident bird species } & \multicolumn{8}{|c|}{ Surveyed localities } \\
\hline & & \multirow[t]{2}{*}{ Common name } & \multirow[t]{2}{*}{ Scientific name } & \multicolumn{4}{|c|}{ Tanta locality } & \multicolumn{4}{|c|}{ Zifta locality } \\
\hline & & & & B & $\mathbf{F}$ & $\mathrm{T}$ & W & B & $\mathrm{F}$ & $T$ & $\mathrm{~W}$ \\
\hline \multirow{3}{*}{ Charadriiformes } & Burhinidae & Sengal thick knee & Burhinus senegalensis & + & - & + & + & + & + & + & $t$ \\
\hline & Charadridae & Spur-winged plover & Hoplopterus spinosus & $H$ & $H$ & $H$ & $H$ & - & + & - & + \\
\hline & Scolopacidae & Greater painted snipe & Rostratula benghalensis & $H$ & $H$ & $H$ & $H$ & - & - & - & - \\
\hline \multirow[t]{3}{*}{ Ciconiformes } & \multirow{3}{*}{ Ardeidae } & Cattle egret & Bubulcus ibis ibis & $H$ & $*$ & $H$ & $H$ & $H$ & $H$ & $*$ & \\
\hline & & Little egret & Egretta garzetta & - & - & + & + & - & $H$ & + & $H$ \\
\hline & & Squacco heron & Ardeola ralloides & - & - & - & + & - & - & - & + \\
\hline Columbiformes & Columbidae & Palm dove & Streptopelia senegalensis & $+H$ & H & $H$ & $+H$ & $H$ & $+H$ & + & $+H$ \\
\hline \multirow[t]{2}{*}{ Coraciformes } & \multirow[t]{2}{*}{ Cerylidae } & Peid king fisher & Ceryle rudis & - & H & + & + & - & - & - & H \\
\hline & & Blue cheeked bee-eater & Merops orientalis & $H$ & H & $H$ & $H$ & - & - & - & $H$ \\
\hline Cuculifornes & Centropidae & Senegal coucal & Centropus senegalensis & + & + & - & - & - & - & - & - \\
\hline Falconiiformes & Falconidae & Kestrel & Falco tinnunculus & - & - & + & - & - & - & + & + \\
\hline \multirow[t]{2}{*}{ Gruiiformes } & \multirow[t]{2}{*}{ Rallidae } & Moorhen & Gallinula chloropus & $H$ & H & $H$ & $H$ & + & - & - & $H$ \\
\hline & & Water rail & Rallus aquaticus & - & - & + & + & - & - & - & - \\
\hline \multirow{9}{*}{ Passeriformes } & Alaudidae & Crested lark & Galerida crestata & - & + & - & + & - & - & - & - \\
\hline & \multirow[t]{2}{*}{ Cisticolidae } & Fantail warbler & Cisticola juncidis & $H$ & H & $H$ & $H$ & $H$ & $H$ & $H$ & $H$ \\
\hline & & Graceful warbler & Prinia gracilis & - & $H$ & $H$ & $H$ & - & - & - & - \\
\hline & Corvidae & Hooded crow & Corvus corone cornix & $H$ & H & $+H$ & $H$ & $H$ & $H$ & H & H \\
\hline & Hirundidae & Swallow & Hirundo rustica savignii & $H$ & $*$ & $H$ & $H$ & $H$ & $H$ & & $*$ \\
\hline & Motacillidae & yellow wagtail & Motacilla flava & * & $H$ & * & $H$ & - & - & - & - \\
\hline & Nectariniidae & Nile valley sunbird & Anthreptes metallicus & $H$ & H & $H$ & $H$ & $H$ & $H$ & $*$ & H \\
\hline & Passeridae & House spartow & Passer domesticus niloticus & * & $H$ & * & $*$ & $H$ & $H$ & $+H$ & $*$ \\
\hline & Pycnonotidae & Common bulbul & Pycnonotus barbatus & - & - & + & + & - & - & - & + \\
\hline Strigiformes & Strigidae & Little owl & Athene noctua & - & - & $H$ & + & - & - & - & - \\
\hline Upupiformes & Upupidae & Hoopoe & Upupa epops & + & - & - & - & $H$ & - & - & + \\
\hline
\end{tabular}


Order Strigiformes with family Strigidae was represented by one bird species Little owel Athene nuctua as beneficial bird species found in Tanta district only.

Order Upupiformes including one family Upupidae was represented by one bird species Hoope Upupa epops as beneficial bird species was found in two districts.

The obtained data explained that, Cattle egret Bubulcus ibis ibis, House sparrow Passer domesticus niloticus and Swallow Hirundo rustica savignii were found in a high numbers in the two districts throughout the whole period of the study beginning from October 2012 to September 2014.

Also, Hooded crow Corvus corone cornix was found in a high numbers in Zifta district; while it was found in moderate numbers in Tanta district. And Yellow wagtail Motacilla flava was found in high numbers in Tanta district; while it was completely absent in Zifta district.

Also, Grecful warbler Prinia gracilis and Greater Painted snipe Rostratula benghalensis were found in moderate numbers in Tanta district; while they were completely absent in Zifta district.

On the other hand, Little owel Athene nuctua and Water rail Rallus aguaticus were found in a few numbers in Tanta district; while they were completely absent in Zifta district.

These results coincided with these obtained by Goodman et al. (1989) who reported that Hooded crow, Corvus corone cornix was common resident in most cultivated parts of the Nile Delta and Valley (South to Aswan Governorate), along the Suez Canal, in the Faiyoum Governorate, and North-Eastern Sinai. (Essa 1993, Khattab 1993, Wilson 1993) and El-Mallah (2004) observed and classified birds in two groups, the first was beneficial birds and the second was noxious birds. Omar (2005) surveyed 23 resident bird species and 5 migratory bird species under the different orders in Assiut Governorate. Attia (2006) recorded some species of orders Passeriformes, Gruiformes, Falconiformes,
Ciconiformes, Columbiformes, Coraciformes, Cucuali-formes and Upupiformes as resident bird species.

El-Danasory (2006) recorded the resident birds in El- Behira and El-Menoufia governorates. Omar (2010) cleared that bird species in Assiut district included two types of birds, beneficial and noxious. The beneficial birds included Ardeola ibis, Hoopoe Upupa epops, , White wagtail Motacilla alba, Common bulbul ,Pycnonotus barabtus, Fantailed warbler Cisticola juncidis, Kestrl Falco tinnuculus, Swallow Hirundo rustica, Spur winged plover Hoplopterus spinosus,, Northern wheater Oenanthe oenanth and rufous tailed robin Cercotrichas galactotes. Attia (2013) cleared that at Ismailia Governorate, 15 species were recorded as harmful birds and 12 species were recorded as beneficial birds belonging to 20 families and 9 orders.

\section{Survey and distribution of some migratory birds:}

Data in Table (2) showed five bird species as migratory birds were recorded during the study period were as follow, two species were recorded as harmful birds and three species were recorded as beneficial birds belonging to four families and three orders as follow:-

Order Charadriiformes including two bird species were recorded as harmful bird species Common sandpiper Actitis hypoleucos and Snipe Gallinago gallinago belonging to family Scolopacidae were found in moderate numbers in Zifta district and in few numbers in Tanta district.

Order Ciconiiformes was represented by one bird species, White stork Ciconia ciconia as harmful bird species belonging to family Ciconiidae was found in moderate numbers nearby (trees and water canals) in Tanta district only and Kingfisher Alcedo atthis belonging to family Alcedinidae and order Coraciiformes was found in moderate numbers in two district as harmful bird species. 
Metwally, et al.,

Table (2): Survey and distribution of some migratory wild bird species at Gharbia Governorate during October 2012 to September 2014

\begin{tabular}{|c|c|c|c|c|c|c|c|c|c|c|c|}
\hline \multirow{3}{*}{ Orders } & \multirow{3}{*}{ Families } & \multicolumn{2}{|c|}{ Migratory bird species } & \multicolumn{8}{|c|}{ Surveyed localities } \\
\hline & & \multirow{2}{*}{ Common name } & \multirow{2}{*}{ Scientific name } & \multicolumn{4}{|c|}{ Tanta locality } & \multicolumn{4}{|c|}{ Zifta locality } \\
\hline & & & & B & $\mathbf{F}$ & $\mathrm{T}$ & $\mathbf{W}$ & B & $\mathbf{F}$ & $T$ & $\mathbf{W}$ \\
\hline Ciconifformes & Ciconiidae & White stork & Ciconia ciconia & - & - & ++ & t+ & - & - & - & - \\
\hline Coraciiformes & Alcedinidae & King fisher & Alcedo atthis & - & H & + & H & + & + & + & H \\
\hline \multirow{2}{*}{ Charadriiformes } & \multirow{2}{*}{ Scolopacidae } & Common sandpiper & Actitis hypoleucos & - & - & + & +t & - & - & - & + \\
\hline & & Snipe & Gallinago gallinago & - & - & + & + & - & - & t+ & t+ \\
\hline Passeriformes & Motacillidae & White wagtail & Motacilla alba alba & H & t+ & + & +t & ++ & ++ & + & t+ \\
\hline
\end{tabular}

\# B= Buildings $\quad \begin{gathered}F=\text { Field crops } \quad T=\text { Trees } \quad W=\text { Water canal } \\ -=\text { Absent }\end{gathered}+=1<10 \quad++=10<100 \quad{ }^{*}=100<500$

One bird species belonging to order Passeriformes was recorded as beneficial bird species, White wagtail Motacilla alba alba belonging to family Motacillidae found in moderate numbers in two districts.

Our results agree with som author (Khattab 1998; Soliman 1999; El-Danasory 2002 and 2006; El-Malah 2004 and Attia 2006) recorded Motacilla alba, Alcedo atthis, Phelloscobus collybita and Saxicola torquata as migratory birds.

Attia (2013) cleared that at Ismailia Governorate six bird species were recorded as migratory birds, Motacilla alba, Alcedo atthis, Carduelis cannabina, Phelloscobus collybita, Saxicola torquata and Ciconia ciconia.

\section{REFERENCES}

Attia, M. A. I. (2006). Ornithological studies on some dominant species under the different Agroecosystems at Sharkia Governorate. M.Sc. Thesis, Fac. Agric., Al - Azhar Univ.

Attia, M. A. I. (2013). Studies on some wild bird species at Ismailia Governorate. Ph. D. Thesis, Fac. Agric., Al - Azhar Univ.

Bonnah, A. A. M. M. (2007). The damage and control of Hooded crow on some plantation in Sohag Governorate. Ph.D.
Thesis, Faculty of Agric., Assiut Univ., Egypt, 116 pp.

EI - Danasory, M. A. (2002). Ecological and biological studies on some harmful birds for plants at Minoufia Governorate. M. Sc. Thesis, Fac. of Agric., Al- Azhar Univ.

El - Danasory, M. A. (2006). Studies on some wild bird species in Egypt. Ph. D. Thesis Fac. of Agric. Al-Azhar Univ.

El - Deeb, H. I., M. A. Metwally, A. M. Abdel-Aal and M. M. Khattab (1995). Ecological and biological studies on some wild birds at Sharkia Governorate Al - Azhar. J. Agric., Res., Vol. 21. PP. $425-438$.

El-Malah, S. M. A. (2004). Ecological studies on certain vertebrate pests and their loses in relation to concomitant acari with these pests in Sadat region.M. SC. Thesis Fac. Agric. Minoufia Univ.

Essa, N. H. (1993). Ecological and toxicological study on harmful and useful bird in Egyptian crops PhD. Thesis Inst. of Environ. Studies and Research Ain Shams Univ.

Goodman, S. M., P. L. Meininger and W. C. Mullie (1989). The birds of Egyptian western desert. Mich. Mus.

Hassan, E. Kh. K. (2008). Environmental problems in relation to Corvidae birds and their management in west and east 
Delta. M.Sc. Thesis, Inst. of Enviro. Studies and Res. Ain Shams Univ.

Khattab, M. M. (1993). Biological, Ecological and Toxicological studies on harmful birds of agriculture and of Sharkia Governorate. M.Sc. Thesis Fac. Agric., Al - Azhar Univ. PP.199.

Khattab, M. M. (1998). Ecological studies on some wild bird species at Sharkia Governorate. Ph. D. Thesis Faculty of Agric., Al - Azhar Univ. PP.192.

Khattab, M. M. (2002). Field study on population fluctuation of Hooded crow, Corvus corone saronius (KleinSchmidt), at Sharkia Governorate. $2^{\text {nd }}$ International Conference, Plant protection Research Institute, Cairo, Egypt.21-24 December 2002. PP.115- 120.

Khattab, M. M., S. A. Ismail, A. M. Soliman and H. I. EL-Deeb (2002). Damage assessment due to Hooded crow Corvus corone sardonius (Kleinschmidt) at some cultivated plant crops at newly reclaimed fields in Sharkia Governorate. $\quad 2^{\text {nd }} \quad$ International Conference, Plant protection Research Institute, Cairo, Egypt.21-24 December 2002. PP.88- 91.

Omar, M. M. A. (2005). Ecological and biological studies on some wild birds. $M$. Sc. Thesis Fac. of Agric. Al- Azhar Univ.
Omar, M. M. A. (2010). Studies on some wild birds in Assiut with special reference to harmful birds and its control. Ph.D. Thesis Fac. of Agric. Al-Azhar Univ.

Redinger, R. F. and S. L. Libay (1979). Perches courted with glue reduce bird damage in rice field plots. Proceeding Eighth bird control, seminar, Bowling green, Ohio, Nov. PP. $201-206$.

Sibley, C. C. and L. B. Monoroe (1990). Distribution and taxonomy of birds of the world. New Haven Yale University press. pp. 34-38.

Soliman, A. M. A. (1999). Eco- Biological studies on some wild bird species at Kafr El-Sheikh Governorate with species reference to some Arthropods. Ph.D. Thesis. Fac. Agric., Zagazig Univ.

Tharwat, E. M. (1997). Birds known to occur in Egypt. Department of Nature Protection. Egyptian Environmental Affairs Agency (EEAA), Cabinet of ministers, Arab Republic of Egypt.

Wilson, B. M. (1993). Integrated approaches for population management of harmful birds in agriculture areas of Egypt. Ph.D. Thesis of Environ. Studies and Res. Ain Shams Univ. 


\section{حصر وتوزيع الطيور البرية المقيمة والمهاجرة في بيئات مختلفة في محافظة الغربية}

عبدالستار محمد متولى (1) ، مصطفى عبداللطيف مصطفى (1) ، هاله محمد جمال الاين(2) ،

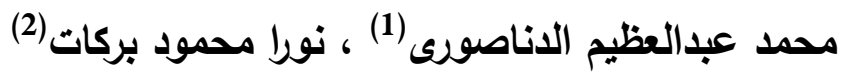

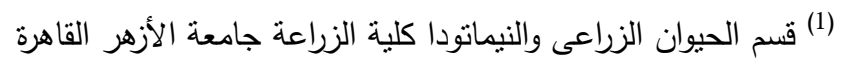

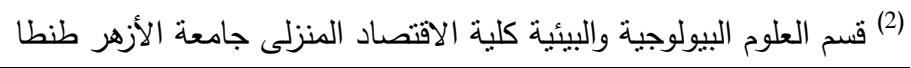
الملخص العربى المبل

تهذف هذه الدراسة إلى حصر بعض أنواع الطيور البرية (الضارة والنافعة في بعض مراكز محافظة الغربية).

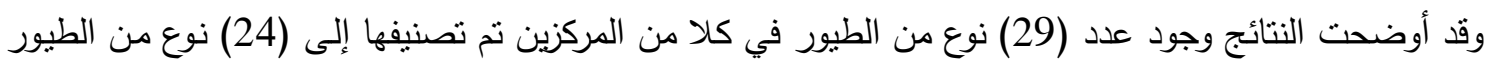

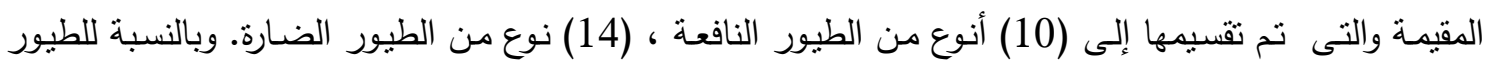

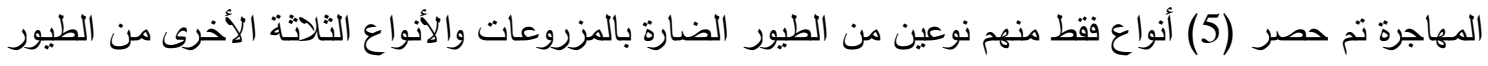

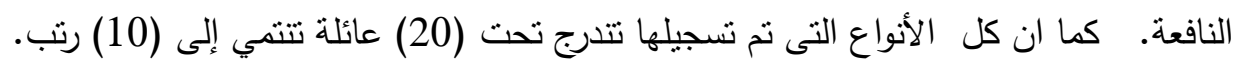

